\title{
The Acidity Level (pH) of Saliva of People in Living in High Radon Level Areas and Its Correlation with the Prevalence of Caries
}

\author{
Dhea Ferrani Permatasari ${ }^{1}$, Irmaleny ${ }^{2}$, Suhardjo Sitam ${ }^{3}$, Ervin Rizali ${ }^{4}$ \\ ${ }^{1}$ Faculty of Dentistry, Universitas Padjadjaran, Bandung 40134, Indonesia \\ ${ }^{2}$ Department of Conservative Dentistry, Faculty of Dentistry, Universitas Padjadjaran, Bandung \\ 40134, Indonesia \\ ${ }^{3}$ Department of Dental Radiology, Faculty of Dentistry, Universitas Padjadjaran, Bandung \\ 40134, Indonesia \\ ${ }^{4}$ Department of Oral Biology, Faculty of Dentistry, Universitas Padjadjaran, Bandung 40134, \\ Indonesia \\ *Email:drg_irmaleny@yahoo.co.id
}

\begin{abstract}
Radon radiation impairs saliva secretion and lowers normal pH levels, which in turn alters the balance of normal oral microflora and leads to caries progression. The aim of this research is to determine the acidity level $(\mathrm{pH})$ of saliva of people living in high radon level areas and its correlation with the prevalence of caries. This study consisted of an observational, cross-sectional survey. The participants were 26- to 45-years-old, had been living in the sampled villages for 10 years or more, had graduated from elementary school, were not active smokers or alcoholics, did not have systemic diseases, did not take illegal drugs, and did not use orthodontic appliances or prostheses. A total of 100 people participated, 54 of wh lived in an area with high radon levels and 46 of which lived in an area with low radon levels. Salivary $\mathrm{pH}$ was measured by a digital $\mathrm{pH}$ meter, and the prevalence of caries was estimated based on the Decayed Missing Filled Teeth Index by the World Health Organization. In areas with high radon levels, the correlation coefficient between the acidity level $(\mathrm{pH})$ of saliva and the prevalence of caries in areas with high radon levels was calculated as 0.062 by the Pearson correlation test. Based on this finding, researchers concluded that there is no correlation between the acidity level $(\mathrm{pH})$ of saliva and the prevalence of caries in people living in areas with high radon levels.
\end{abstract}

Keywords: saliva, caries prevalence, radon

\section{Introduction}

Lorem Radon is a gas that is odorless, colorless, and tasteless. It is produced by the natural decay of uranium, which is a naturally radioactive material found in rocks, soil, and water, and therefore is found primarily in rocky and mountainous areas. Radon's half-life is 3.8 days [1,2]. When radon is released from rocks and soil, it is quickly diluted into the atmosphere where it easily enters poorly ventilated buildings, caves, mines, and tunnels, where is trapped reaching dangerously high concentrations [3,4]. The United Nations Scientific Committee on the Effects of Atomic 
Radiation stated that radon is the biggest natural source of ionizing radiation in many countries around the world [1].

Radon and its progeny emit a high ionizing radiation of alpha particles and have dangerous effects on human health through their inhalation, ingestion, and absorption. For example, the accumulation of radon and alpha particles in the human body can cause genetic damage and cell death. Radiation can also cause dysfunction of the salivary glands [4-6].

Saliva has a mean potential of hydrogen $(\mathrm{pH})$ between 6.75 and 7.25 , which promotes the growth of many microorganisms. The ionic composition of saliva supports its buffering function and ability to remineralize enamel [7]. The buffering capacity of saliva refers to its ability to change its acidity level, and this plays an important role in the development of caries as saliva neutralizes the acid produced by bacteria [8].

Many researchers have conducted studies on radon radiation and its effects on human health. For example, a group of researchers in Europe performed a collaborative analysis of the association of radon radiation in houses with the risk of lung cancer in 13 case-control studies. They found that radon gas caused $2 \%$ of cancer patient deaths and $9 \%$ of lung cancer patient deaths [9]. In addition, in 2005, Brand et al. found that an indoor radon level of $28 \mathrm{~Bq} / \mathrm{m}^{3}$ in Canada caused 1,400 lungs cancer deaths. Also, the Advisory Group on Ionizing Radiation (AGIR) stated that a mean radon level of $21 \mathrm{~Bq} / \mathrm{m}^{3}$ in the United Kingdom caused 1,089 to 2,005 lung cancer deaths. Rericha et al. found a positive correlation between radon radiation and leukemia, including chronic lymphocytic leukemia. Also, an environmental research by Bolviken in 2003 revealed a correlation between multiple sclerosis and indoor radon concentrations [1].

However, there is a lack of studies on the correlation between radon and oral health, including the salivary glands and teeth. Salivary glands are very sensitive to radiation, especially acinar cells since radiation can cause disturbances in proliferation, break double-stranded DNA, and trigger acinar cell death [10]. Radon radiation can cause tongue, oral, and salivary gland cancer [9], as well as cause the salivary glands to become fibrotic and reduce the secretion of saliva [11]. Changes in the salivary glands and saliva secretion can cause an imbalance in the normal oral microflora thereby decreasing the cleansing function of saliva [12]. When this happens, cariogenic microorganisms (e.g., Streptococcus mutans, Lactobacillus, and Candida sp.) are present at higher levels than noncarcinogenic microorganisms $[13,14]$.

One study was conducted in West Java, Indonesia, specifically in the Padalarang area, based on a rock dispersion map. This research revealed that there were both high radon levels (around Gunung Masigit; $24.8 \pm 29 \mathrm{~Bq} / \mathrm{m}^{3}$ ) and low radon levels (around Cipatat; $16.6 \pm 24 \mathrm{~Bq} / \mathrm{m}^{3}$ ) in this area.[15] The prevalence of caries in these two villages was calculated, and the researchers noted that people living in the area with high radon levels had a high prevalence of caries, while the people living in the area with low radon levels had a more moderate prevalence of caries [16]. Therefore, based on these findings, the objective of the current study was to determine whether there was a correlation between salivary $\mathrm{pH}$ and the prevalence of caries among people living in the area with high radon levels, namely Gunung Masigit. 


\section{Material and Methods}

This study was an observational, cross-sectional survey with a comparison group. The inclusion criteria were: individuals between the ages of 26- and 45-years-old, had been living in the village area for at least 10 years and had graduated from elementary school. Participants were excluded if they were active smokers and/or drinkers, if they had systemic diseases, if they consumed any kind of prescription medication, and if they used orthodontic appliances and/or prostheses. The total sample was 100 people, 54 of which were residents of the area with high radon levels (Gunung Masigit) and 46 of which were residents of the area with low radon levels (Cipatat).

\subsection{Material}

1. WHO Oral Health Assessment Form for Adults

2. Plastic cups

3. Dental instruments (dental mirror and probe)

4. Digital $\mathrm{pH}$ meter (Hanna HI 98107)

5. Calibration solution ( $\mathrm{pH} 4$ and 7)

6. Stopwatch

7. White rice

\subsection{Methods}

This Caries was examined based on the Decayed Missing Filled Teeth (DMFT) Index with a mouth mirror and probe. Based on the total value of the DMFT (Decay, Missing, Filing Teeth) Index, each participant was then classified into one of four categories: very low $(<5.0)$, low $(5.0$ to 8.9$)$, moderate (9.0 to 13.9$)$, and high $(>13.9)$. Stimulated saliva was collected using the spitting method after chewing a tablespoon of white rice for 5 minutes. The acidity level or $\mathrm{pH}$ of the saliva was measured using a digital $\mathrm{pH}$ meter and then categorized into three different groups based on the DMFT index: normal (6.75 to 7.25), acidic $(<6.75)$, and basic $(>7.25)$. The data were input into Microsoft Excel 2016 and then processed using SPSS Statistics v23. The correlation value was calculated with the Pearson correlation test. 


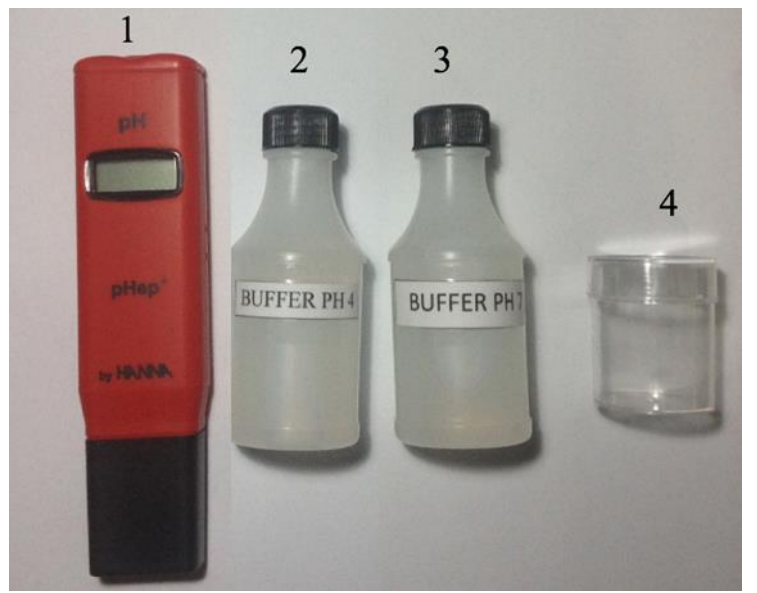

Fig 1. Instruments to calculate salivary pH: (1) digital pH meter, (2) calibration solution pH 4, (3) calibration solution pH 7, and (4) plastic cup.

\section{Result and Discussion}

Table 1 presents participant data, including sex, age, caries index, and salivary $\mathrm{pH}$. As can be seen in Table 1, the caries index in Cipatat and Gunung Masigit was very low and did not indicate any effect from different levels of radon radiation. The salivary $\mathrm{pH}$ in Cipatat was mostly basic, while in Gunung Masigit it was mostly acidic. Table 2 shows the mean values of the caries index and salivary $\mathrm{pH}$, and Table 3 presents the correlation between the caries index and salivary $\mathrm{pH}$ values.

The caries index in both areas (with low radon levels and high radon levels) was low (see Table 1). This finding is different from the research conducted in these same villages in 2016, which noted that the area with low radon levels was categorized by a moderate prevalence of caries, while the area with high radon levels was categorized by a high prevalence [16]. In the current study, there was an insignificant difference between the caries index results of the two areas. However, it should be noted that participants in the current study were not the same as those in the previous study, and differences in oral hygiene, lifestyle, food consumption, sources of drinking water, immune system defense properties, and the use of fluoride can cause different rates of caries development [11].

In the current study, the salivary $\mathrm{pH}$ of people living in the area with low radon levels was categorized as normal, while it was categorized as acidic for the people living in the area with high radon levels (see Table 2). This difference in salivary $\mathrm{pH}$ could be caused by environmental factors [17], which would include radon levels.

The value of the correlation coefficient ( $r$ ) for Cipatat was -0.324 , which shows that there is a weak correlation between the two variables (Table 3 ). In addition, the $\mathrm{p}$-value was lower than the significance value, which was 0.05 . This result shows that there was a correlation between the caries index and salivary $\mathrm{pH}$ in Cipatat. Salivary flow, composition, and $\mathrm{pH}$ all play important roles in the development of caries [18-21]. A negative value for a correlation coefficient indicates an inverse 
relationship so that if the caries index is high, the salivary $\mathrm{pH}$ will be low. This result is similar to research conducted by Shetty et al. in 2013 [19]. In the current study, the correlation coefficient between the caries index and salivary $\mathrm{pH}$ in Gunung Masigit was -0.062 . This value indicates that there was a weak correlation between the two variables. The p-value of 0.655 was larger than the significance value of 0.05 , which means that no statistically significant correlation existed between the caries index and salivary $\mathrm{pH}$ in Gunung Masigit. Research by Seethalakshmi in 2016 and Rovelstad in 1966 also found no significant correlation between variables. In addition, a negative value means that if the caries index is higher, the salivary $\mathrm{pH}$ will be lower. This inverse relationship can be caused by oral hygiene habits which were not factored into the current study. There are different opinions regarding the importance of $\mathrm{pH}$ saliva in the development of caries; nevertheless, salivary $\mathrm{pH}$ has been found to have a weak correlation with the prevalence of caries [22,23].

The results of correlation tests in both Gunung Masigit and Cipatat were not in line with the hypothesis and may have been caused by different radon dosages received by participants. Radon and its progeny can come from different sources, and people who live in an area with high radon levels are not always exposed to the same amount of radiation. This difference in exposure levels can also be impacted by the number of radon particles that one inhales and/or ingests. In addition, the topography, type, and construction materials of one's house, environmental factors (e.g., water source, soil below the house, ventilation, and wind velocity), and lifestyle can all affect an individual's radon exposure.

In the future, researchers should investigate correlations between the development caries and bacteria, food, the demineralization process of teeth, biofilm $\mathrm{pH}$, the use of fluoride, oral hygiene, the immune system, genetic factors, socioeconomic status, lifestyle, tribe affiliation, sex, and occupation. In addition, researchers should collaborate with geologists so that soil and rock samples are precisely and accurately collected and analyzed.

\section{Conclusion}

The results of this study show that there is no correlation between the acidity of saliva $(\mathrm{pH})$ and the prevalence of caries in people living in areas with high radon levels.

\section{References}

1 Angell WJ, Zeeb H, Shannon F. WHO handbook on indoor radon: a public health perspective.1st ed. France: World Health Organization; 2009. 3-14 p.

2 Environmental Protection Agency [Internet]. United States: EPA; c2015 [cited 2016 May 16]. Available from: http://www.epa.gov/radon.

3 Finkelman RB, Centeno JA, Selinus O. The emerging medical and geological association. Trans Am Clin Climatol Assoc. 2005; 116:155.

4 Orfano F. The effects of alpha radiation on humans. Bright Hub [Internet]. [cited 2016 May 25]. Available from: http://www.brighthub.com/environment/science-environmental/articles/85643.aspx. 
5 Ames E. Health notes: health effects of radiation. Western Washington University. 2007 [cited 2016 May 25];1-2. Available from: http://www.wwu.edu/wwura/1105.pdf.

6 Konings AWT, Coppes RP, Vissink A. On the mechanism of salivary gland radiosensitivity. Int J Radiat Oncol Biol Phys [Internet]. 2005 [cited 2016 May 20];62(4):1189. Available from: http://www.redjournal.org.

7 Marsh PD. Role of the oral microflora in health. Microb Ecol Health Dis. 2000 ;12(3):130-7.

8 Florence AT, Attwood D. Physiochemical principles of pharmacy. 5th ed. London: Pharmaceutical Press; 2011. 82 p.

9 Darby S, Hill D, Auvinen A, Barros-Dios JM, Baysson H, Bochicchio F, et al. Radon in homes and risk of lung cancer: collaborative analysis of individual data from $13 \mathrm{Eu}-$ ropean case-control studies. BMJ. 2005;330(7485):223.

10 Grundmann O, Mitchell GC, Limesand KH. Sensitivity of salivary glands to radiation: from animal models to therapies. JDR[Internet]. 2009 [cited 2016 May 10];88(10):894903. Available from: http://www.pubmedcentral.nih.gov.

11 Heymann HO, Swift EJ, Ritter AV. Sturdevant's art and science of operative dentistry. 6th ed. Canada: Elsevier: 2013. 41 p.

12 White SC, Pharoah MJ. Oral radiology: principles and interpretation. 7th ed. Canada: Elsevier Health Sciences; 2014. 21-22 p.

13 Pinna R, Campus G, Cumbo E, Mura I, Milia E. Xerostomia induced by radiotherapy: an overview of the physiopathology, clinical evidence, and management of the oral damage. Ther Clin Risk Manag. 2015; 11:171.

14 Gupta N, Pal M, Rawat S, Grewal MS, Garg H, Chauhan D, Ahlawat P, Tandon S, Khurana R, Pahuja AK, Mayank M. Radiation-induced dental caries, prevention and treatment-A systematic review. Natl J Maxillofac Surg. 2015;6(2):160.

15 Putra FR. Studi identifikasi unsur radon dalam batuan di wilayah Padalarang, Kabupaten Bandung Barat, Provinsi Jawa Barat. Bandung: Universitas Padjadjaran; 2016. 41-53 p.

16 Putri RM. Prevalensi karies gigi berdasarkan indeks DMF-T di wilayah kadar radon $16,6 \pm 24 \mathrm{~Bq} / \mathrm{m}^{3}$ Desa Cipatat dan $24,8 \pm 29 \mathrm{~Bq} / \mathrm{m}^{3}$ Desa Gunung Masigit. Bandung: Universitas Padjadjaran; 2016. 3-6 p.

17 De Almeida PD, Gregio AM, Machado MA, De Lima AA, Azevedo LR. Saliva composition and functions: a comprehensive review. J Contemp Dent Pract. 2008;9(3):7280.

18 Rudney JD. Does variability in salivary protein concentrations influence oral microbial ecology and oral health? Crit Rev Oral Biol Med. 1995;6(4):343-67.

19 Shetty C, Hegde MN, Devadiga D. Correlation Between Dental Caries with Salivary Flow, Ph, and Buffering Capacity in Adult South Indian Population: An In-Vivo Study. Int J Res Ayurveda Pharm. 2013;4(2):219-23.

20 Barr - Agholme M, Dahllöf G, Modéer T, Engström PE, Engström GN. Periodontal conditions and salivary immunoglobulins in individuals with Down syndrome. J Periodontol. 1998;69(10):1119-23.

21 Benderli Y, Erdilek D, Koray F, Telci A, Turan N. The relation between salivary IgA and caries in renal transplant patients. Oral Surg Oral Med Oral Pathol Oral Radiol Endod. 2000;89(5):588-93

22 Seethalakshmi C, Reddy RJ, Asifa N, Prabhu S. Correlation of salivary pH, incidence of dental caries and periodontal status in diabetes mellitus patients: a cross-sectional study. Journal of clinical and diagnostic research: JCDR. 2016 Mar;10(3): ZC12-14.

23 Cunha-Cruz J, Scott J, Rothen M, Mancl L, Lawhorn T, Brossel K, Berg J. Salivary characteristics and dental caries: evidence from general dental practices. J Am Dent Assoc. $2013 ; 144(5): \mathrm{e} 31-40$. 